\title{
Nutritional and sensory quality assessment of plain cake enriched with beetroot powder
}

\author{
Lucky, A.R., Al-Mamun, A., Hosen, A., *Toma, M.A. and Mazumder, M.A.R. \\ Bangladesh Agricultural University, Faculty of Agricultural Engineering and Technology, Department of \\ Food Technology and Rural Industries, Mymensingh-2202, Bangladesh
}

\section{Article history: \\ Received: 7 June 2020 \\ Received in revised form: 15 July 2020 \\ Accepted: 9 August 2020 Available Online: 29 August 2020}

\section{Keywords:}

Beetroot powder,

Cake,

Nutritional composition,

Sensory evaluation

\section{DOI:}

https://doi.org/10.26656/fr.2017.4(6).268

\begin{abstract}
The study was aimed to develop cake supplemented by beetroot powder and to evaluate its quality parameter. Four samples were prepared to contain different proportions of beetroot powder $(5,10,15$, and $20 \% \mathrm{w} / \mathrm{w})$ in combination with wheat flour. The nutritional and sensory properties of plain cakes were also evaluated. The cake supplemented with $15 \%$ $(\mathrm{w} / \mathrm{w})$ beetroot powder had significantly $(\mathrm{p}<0.05)$ improved the nutritional quality compared to control one (without beetroot powder). The mean sensory scores of highly acceptable beetroot powder cake $S_{3}(85: 15)$ had better color $(8.57 \pm 0.53)$, flavor $(8.43 \pm 0.53)$, texture $(8.29 \pm 0.49)$, taste $(8.57 \pm 0.53)$ and overall acceptability $(8.47 \pm 0.13)$ than other samples. The nutritional and sensory analysis suggested that the cake formulated by $15 \%(\mathrm{w} / \mathrm{w})$ beetroot powder was comparatively more acceptable than other formulations $(0,5,10$ and $20 \% \mathrm{w} / \mathrm{w})$.
\end{abstract}

\section{Introduction}

The demand for bakery products have been increased in the latter part of the $20^{\text {th }}$ century due to the quickly growing economic world and eating practice of the working people due to a shortage of time (Pinki, 2014; Srivastava and Singh 2018). The commonly used baked products are bread, cakes and biscuits (Patil and Pol, 2014). Major contributing factors for increasing the demand for baking product consumption is urbanization, reasonable costs, better shelf life, the taste is good enough, and easy transportation for lightweight. The flours obtained from legumes, tubers, and other cereals products can use vegetable protein and dietary fiber sources for enriching the nutrient contents of this bakery produce (Chavan and Kadam, 1993).

The insufficiency of fiber, iron, calcium, antioxidants and folic acid in bakery products especially, in high sugar items such as cakes, can be made by incorporating beetroot powder with wheat flour to make it healthier and more nutritious. Beetroot is highly acceptable for its rich nutrient contents viz. dietary fiber, mineral contents such as iron, potassium, calcium, zinc, and sodium, and vitamin contents such as vitamin A, B6, folic acid, niacin, biotin and C (Pinki, 2014; Bach et al., 2015; da Silva et al., 2016; Singh et al., 2016). Some essential bioactive compounds like carotenoids (Dias et al., 2009), phenolic compounds, saponins, betaine
(Jastrebova et al., 2003), betalains (antioxidants), polyphenols and flavonoids (Vali et al., 2007) also present in beetroot powder having anti-cancer and therapeutic properties (Neagu and Barbu, 2014). These compounds are having anti-oxidative (da Silva et al., 2016), hepatoprotective, anticancer and antiinflammatory activity (Kavalcova et al., 2015), may improve many clinical outcomes such as hypertension, type-2 diabetes, atherosclerosis and dementia (Clifford et al., 2015). Beetroot contains both betaine and nitrate. Betaine is a trimethyl derivative of amino acid glycine which promotes muscular endurance, strength, and power (Hoffman and Ratamess, 2009).

Inclusion of dietary fiber (DF) to baking produce has many advantages, mainly decreases their caloric density and also increase dietary fiber intake (Elleuch et al., 2011). Incorporation of beetroot powder into the cereal and baking products viz. biscuits, cakes, bread, etc. can be a good source of dietary fiber (Pinki, 2014; Singh et al., 2016). In Bangladesh, there was no such study taken into consideration to assess the benefits of beetroot powder applications in easily consumable bakery products such as cake. Also considering the poor people in our country going through malnutrition, the study was designed to prepare the cakes by integrating $5-20 \%(\mathrm{w} /$ w) of beetroot powder and assess the nutritional and sensory composition. 


\section{Materials and methods}

\subsection{Materials}

Wheat flour, eggs, sugar, vanilla essence, powder milk, baking powder, shortening (soybean oil) and other materials used in the study were brought from local market of Mymensingh, Bangladesh. Analytical Reagent grade chemicals and solvents were used in the study.

\subsection{Processing of beetroot powder}

Raw beetroot was brought from the local market and cleaned properly to remove foreign materials. Then trimmed properly and was sliced into thin pieces $(3 \mathrm{~mm})$ with the help of slicer (Choudhury 1996). Sliced beetroot was blanched at $80^{\circ} \mathrm{C}$, followed by drying at $55^{\circ} \mathrm{C}$ for 4 hours by a cabinet drier. Dried beetroot was ground to a fine powder (65 mesh size sieve) and packed in airtight colored glass bottles for further use (Srivastava and Singh 2016).

\subsection{Proximate composition of beetroot powder}

Proximate chemical composition analysis of both beetroot powder and wheat flour was done, including moisture and ash were measured following the method of the Association of Official Analytical Chemists (AOAC, 2000). Fat content was analyzed using the Soxhlet extraction method, protein content using Kjeldahl method (AOAC, 2005) and total dietary fiber using enzymatic-gravimetric method (AOAC, 2003).

\subsection{Formulation of cakes}

Beetroot powder incorporating cakes were prepared by replacing wheat flour with different proportions of beetroot powder. Using wheat flour and beetroot powder (BRP), four different types of beetroot cakes were made by using wheat flour and beetroot powder (BRP) in a ratio of 95:05 $\left(\mathrm{S}_{1}\right), 90: 10\left(\mathrm{~S}_{2}\right), 85: 15\left(\mathrm{~S}_{3}\right)$ and 50:20 $\left(\mathrm{S}_{4}\right)$. All the ingredients used for the preparation of cakes were given in Table 1. For preparing cakes, at first, sieved wheat flour and beetroot powder were mixed at different proportion $(5,10,15$ and $20 \% \mathrm{w} / \mathrm{w})$. Baking soda was mixed thoroughly with the mixture along with other ingredients (wheat flour, beetroot powder, sugar, baking soda, oil, milk powder, eggs and vanilla essence). The batter was poured in a pre-greased mould and baked at $160-180^{\circ} \mathrm{C}$ for $20-30$ mins (Srivastava and Singh, 2018).

\subsection{Nutritional analysis of cakes containing beetroot powder}

Beetroot powder cakes were analyzed for obtaining nutritional composition (AOAC, 2000). The energy value of cakes in kcal per $100 \mathrm{~g}$ was also determined following Mudambi et al. (1989).

\subsection{Sensory characteristics}

The panel of ten panelists judged the cakes for sensory evaluation are the students of the Department of Food Technology and Rural Industries have enough knowledge of sensory characteristics. The panelists evaluated the cakes according to the Score Card method to assess the sensory parameters viz. color, texture, flavor, taste, and overall acceptability (Amerine et al., 2013). The obtained values from the panelists were then evaluated by one-way ANOVA.

\subsection{Statistical analysis}

The obtained data were analyzed statistically summarized in the form of the mean and standard deviation to find out correlations among the parameters (Panse and Sukhatme 1961). The effects of beetroot powder on the chemical composition and sensory characteristics of the formulations were analyzed using one-way ANOVA. To describe the significant differences between the control one and samples incorporated with different percentages of beetroot powder, a multiple range test (Fisher's least significant differences) procedure was applied.

\section{Result and discussion}

\subsection{Chemical composition of beetroot powder}

The nutritional compositions of beetroot powder and wheat flour are shown in Table 2. Data in Table 2 suggested that wheat flour contains higher fat content than beetroot powder. The similar result was obtained by

Table 1. Formulation of cakes using Beetroot powder

\begin{tabular}{lccccc}
\hline \multirow{2}{*}{ Ingredients } & \multirow{2}{*}{ Control Cake } & \multicolumn{4}{c}{ Beetroot powder incorporated cakes } \\
\cline { 2 - 6 } & & \multicolumn{4}{c}{ Wheat flour: Beetroot powder } \\
\cline { 2 - 6 } & $\mathrm{S}_{0}$ (control) & $\mathrm{S}_{1}(5 \% \mathrm{BRP})$ & $\mathrm{S}_{2}(10 \%$ BRP) & $\mathrm{S}_{3}(15 \%$ BRP) & $\mathrm{S}_{4}(20 \% \mathrm{BRP})$ \\
\hline Wheat flour $(\mathrm{g})$ & 100 & 95 & 90 & 85 & 80 \\
Beetroot powder $(\mathrm{g})$ & 0 & 5 & 10 & 15 & 20 \\
Sugar $(\mathrm{g})$ & 80 & 80 & 80 & 80 & 80 \\
Oil (mL) & 82 & 82 & 82 & 82 & 82 \\
Milk powder $(\mathrm{g})$ & 4.5 & 4.5 & 4.5 & 4.5 & 4.5 \\
Egg (nos.) & 4 & 4 & 4 & 4 & 1.8 \\
Baking powder $(\mathrm{g})$ & 1.8 & 1.8 & 1.8 & 1 & 1 \\
Vanilla Essence $(\mathrm{mL})$ & 1 & 1 & 1 & 1.8 & 1 \\
\hline
\end{tabular}


Kohajdova et al. (2018). Beetroot powder contains a significantly higher amount of protein, ash, and dietary fiber than wheat flour. Elleuch et al. (2011) also found the same results. Beetroot powder may be considered as a dietary fiber (55.18\%) product as it contains more than $50 \%$ total dietary fiber and less than $9 \%$ moisture content (7.20\%) reported by Larrauri (1999) and Figuerola et al. (2005). Beetroot powder is also a good source of ash (3.57\%), which might indicate a good source of minerals.

Table 2. Proximate composition of wheat flour and beetroot powder

\begin{tabular}{lcc}
\hline Nutrients & $\begin{array}{c}\text { Wheat flour } \\
\text { (mass \%) }\end{array}$ & $\begin{array}{c}\text { Beetroot powder } \\
\text { (mass \%) }\end{array}$ \\
\hline Moisture & $11.72 \pm 0.63$ & $7.20 \pm 1.15$ \\
Protein & $10.73 \pm 0.40$ & $13.01 \pm 0.01$ \\
Fat & $1.78 \pm 0.04$ & $1.58 \pm 0.27$ \\
Ash & $0.52 \pm 0.02$ & $3.57 \pm 0.48$ \\
Total Dietary fiber & $1.97 \pm 0.18$ & $55.18 \pm 0.33$ \\
\hline
\end{tabular}

Values are expressed as mean \pm standard deviation

\subsection{Effect of incorporation of beetroot powder on the nutritional composition of plain cakes}

Data from Table 3 indicates the highest carbohydrate percentage recorded in the sample of $\mathrm{S}_{0}$ (40.43), followed by $\mathrm{S}_{1}$ (37.40), $\mathrm{S}_{2}$ (35.42), $\mathrm{S}_{3}$ (33.30), and $\mathrm{S}_{4}$ (31.86). For protein content, it was observed that the samples $\left(\mathrm{S}_{1}-\mathrm{S}_{4}\right)$ protein contents $(13.57-15.83 \%)$ were higher than the control sample $\mathrm{S}_{0}(13.43 \%)$. Pinki (2014) reported that protein content was increased up to 12.42 $(\mathrm{g} / 100 \mathrm{~g})$ as the level of BRP increased from 0 to 25 per cent. Fat content is higher in sample $\mathrm{S}_{4}(24.02 \%)$ and lower in sample $\mathrm{S}_{0}(21.13 \%)$. Higher ash content was recorded in the sample of $\mathrm{S}_{4}(3.18)$ and lowest in control sample $\mathrm{S}_{0}(1.02)$ as beetroot powder is an enormous source of minerals (Kohajdova et al., 2018). In terms of moisture content, the highest moisture percentage was recorded in the sample of $S_{1}$ (23.40), followed by $S_{0}$ (22.76), $\mathrm{S}_{2}$ (22.97), $\mathrm{S}_{3}$ (22.58) and $\mathrm{S}_{4}$ (23.02). The dietary fiber content is higher in sample $\mathrm{S}_{4}(2.43)$ and lower in sample $\mathrm{S}_{0}(0.53)$. Thus, the nutritional composition of cakes figured that protein content increased from $13.43 \%$ to $15.83 \%$, ash content from $1.02 \%$ to $3.18 \%$ and dietary fiber from $0.53 \%$ to $2.43 \%$ as the percentage of beetroot powder increased from 0 to $20 \%$. The similar results were also observed by Nazni and Karuna Thara (2011) where ash and fibre contents were increased with the increment of beetroot powder percentages in the cake. Fat content and energy decreased from $21.63 \%$ to $21.59 \%$ and energy from 410.07 to 394.75 (kcal/100 g), respectively, as the percentage of beetroot powder increased from 0 to $20 \%$.

\subsection{Sensory evaluation}

Consumer acceptability based on color, flavor, texture, taste, and overall acceptability of the samples, are shown in Table 4. Values in Table 4 are shown as mean with standard deviation. It was also noted that the cake prepared with $15 \%$ beetroot powder $(\mathrm{w} / \mathrm{w})$ was highly acceptable among other proportions of beetroot cakes and control one. Pinki (2014) reported that cake prepared with 15-20 per cent beetroot powder incorporation had better physical and sensory properties.

\subsection{Cost estimation of cakes}

Cakes were estimated to assess the cost of whether the formulated cake is affordable by general consumers or not if the cakes produced commercially. The

Table 3. Nutritional composition of cakes incorporating beetroot powder

\begin{tabular}{|c|c|c|c|c|c|}
\hline \multirow{2}{*}{$\begin{array}{l}\text { Chemical analysis (\%) } \\
\text { (Parameters) }\end{array}$} & \multicolumn{5}{|c|}{ Beetroot powder incorporated cakes } \\
\hline & $\mathrm{S}_{0}$ (control) & $\mathrm{S}_{1}(5 \% \mathrm{BRP})$ & $\mathrm{S}_{2}(10 \% \mathrm{BRP})$ & $\mathrm{S}_{3}(15 \% \mathrm{BRP})$ & $\mathrm{S}_{4}(20 \% \mathrm{BRP})$ \\
\hline Carbohydrate & 40.42 & 38.09 & 36.45 & 35.57 & 34.28 \\
\hline Moisture & 22.76 & 23.40 & 22.97 & 22.58 & 23.02 \\
\hline Protein & 13.43 & 13.57 & 14.77 & 15.61 & 15.83 \\
\hline Fat & 21.63 & 21.61 & 21.61 & 21.60 & 21.59 \\
\hline Ash & 1.02 & 1.72 & 2.28 & 2.45 & 2.84 \\
\hline Dietary fibre & 0.73 & 1.60 & 1.91 & 2.18 & 2.43 \\
\hline Energy (kcal/100 g) & 410.07 & 401.13 & 399.37 & 399.12 & 394.75 \\
\hline
\end{tabular}

Table 4. Sensory analysis of beetroot powder formulated cakes

\begin{tabular}{lccccccc}
\hline \multirow{2}{*}{ Sensory Attributes } & \multicolumn{6}{c}{ Beetroot powder incorporated cakes } \\
\cline { 2 - 8 } & $\begin{array}{c}\mathrm{S}_{0} \\
(\text { control })\end{array}$ & $\begin{array}{c}\mathrm{S}_{1} \\
(5 \% \mathrm{BRP})\end{array}$ & $\begin{array}{c}\mathrm{S}_{2} \\
(10 \% \mathrm{BRP})\end{array}$ & $\begin{array}{c}\mathrm{S}_{3} \\
(15 \% \text { BRP })\end{array}$ & $\begin{array}{c}\mathrm{S}_{4} \\
(20 \% \mathrm{BRP})\end{array}$ & LSD at 5\% & S.Em \pm \\
\hline Color & $7.86 \pm 0.38$ & $5.43 \pm 0.53$ & $6.14 \pm 0.77$ & $8.57 \pm 0.53$ & $8.14 \pm 0.38$ & 0.566 & 0.610 \\
Flavor & $8.57 \pm 0.53$ & $5.43 \pm 0.53$ & $6.29 \pm 0.75$ & $8.43 \pm 0.53$ & $8.43 \pm 0.53$ & 0.626 & 0.656 \\
Texture & $8.57 \pm 0.53$ & $6.14 \pm 0.69$ & $6.57 \pm 0.98$ & $8.29 \pm 0.49$ & $7.71 \pm 0.49$ & 0.707 & 0.475 \\
Taste & $8.43 \pm 0.53$ & $5.86 \pm 0.69$ & $6.14 \pm 0.77$ & $8.57 \pm 0.53$ & $8.00 \pm 1.15$ & 0.897 & 0.580 \\
Overall acceptability & $8.36 \pm 0.34$ & $5.72 \pm 0.35$ & $6.29 \pm 0.20$ & $8.47 \pm 0.13$ & $8.07 \pm 0.30$ & 0.400 & 0.573 \\
\hline
\end{tabular}


estimated cost of production for control $\left(\mathrm{S}_{0}\right)$ was $\mathrm{Tk}$. 19.50/100 g while for $S_{1}, S_{2}, S_{3}$ and $S_{4}$ were Tk. 23.5/100 g, Tk. $27.6 / 100$ g, Tk. $31.6 / 100 \mathrm{~g}$ and Tk. $35.7 / 100 \mathrm{~g}$, respectively. Cost of cupcake made from wheat flour fortified with beetroot and wheatgrass powder (90:5:5) was reported by Sharma et al (2019) as Rs. 29.4/100 g which was quite similar to the cost of $5 \%$ incorporated beetroot powder cake of the study.

\section{Conclusion}

Beetroot powder, an abundant source of dietary fiber and mineral content can be used in the production of bakery and confectionery products. Protein, fat, ash and fiber contents of different percentages of beetroot powder cakes increased with the increase of beetroot powder. The cake containing $15 \%$ beetroot powder had a better appearance, taste, and texture compared to other cakes. This study suggested that cakes prepared with beetroot powder of $15 \%(\mathrm{w} / \mathrm{w})$ had comparatively better nutritional and sensory characteristics over control one. Therefore, cake with $15 \%$ beetroot powder is advised to consume in our everyday diet for health benefits.

\section{Conflict of interest}

The authors declare no conflict of interest.

\section{References}

Amerine, M., Pangborn, R. and Roessler, E. (2013). Principles of sensory evaluation of food. New York: Academic Press.

AOAC. (2000). Official Methods of Analysis of the Association Official Analytical Chemists. Washington, DC., USA: AOAC.

AOAC. (2003). Official Methods of Analysis of the Association Official Analytical Chemists. Washington, DC., USA: AOAC.

AOAC. (2005). Determination of Moisture, Ash, Protein and Fat. Official Methods of Analysis. 18th ed. Association of Official Analytical Chemists Washington, DC., USA: AOAC.

Bach, V., Mikkelsen, L., Kidmose, U. and Edelenbos, M. (2015). Culinary preparation of beetroot (Beta vulgaris $L$.): the impact on sensory quality and appropriateness. Journal of the Science of Food and Agriculture, 95(9), 1852-1859. https:// doi.org/10.1002/jsfa.6886

Chavan, J.K. and Kadam, S.S. (1993). Nutritional enrichment of bakery products by supplementation with nonwheat flours. Critical Reviews in Food Science and Nutrition, 33(3), 189-226. https:// doi.org/10.1080/10408399309527620
Choudhury B. (1996). Vegetables. $9^{\text {th }}$ ed, New Delhi: National Book Trust.

Clifford, T., Howatson, G., West, D. and Stevenson, E. (2015). The Potential Benefits of Red Beetroot Supplementation in Health and Disease. Nutrients, 7 (4), 2801-2822. https://doi.org/10.3390/nu7042801

da Silva, D.V.T., de Oliveira Silva, F., Perrone, D., Pierucci, A.P.T.R., Conte-Junior, C.A., da Silveira Alvares, T., Del Aguila, E.M. and Paschoalin, V.M.F. (2016). Physicochemical, nutritional, and sensory analyses of a nitrate-enriched beetroot gel and its effects on plasmatic nitric oxide and blood pressure. Food and Nutrition Research, 60, 29909. https://doi.org/10.3402/fnr.v60.29909

Dias, M.G., Camoes, M.F.G.F.C. and Oliveira, L. (2009). Carotenoids in traditional Portuguese fruits and vegetables. Food Chemistry, 113(3), 808-815. https://doi.org/10.1016/j.foodchem.2008.08.002

Elleuch, M., Bedigian, D., Roiseux, O., Besbes, S., Blecker, C.H. and Attia, H. (2011). Dietary fibre and fibre-rich by-products of food processing: characterization, technological functionality and commercial applications: a review. Food Chemistry, 124(2), 411-421. https://doi.org/10.1016/ j.foodchem.2010.06.077

Figuerola, F., Hurtado, M.L., Estevez, A.M., Chiffelle, I. and Asenjo, F. (2005). Fibre concentrates from apple pomace and citrus peel as potential fibre sources for food enrichment. Food Chemistry, 91(3), 395-401. https://doi.org/10.1016/j.foodc hem.2004.04.036

Hoffman, J.R., Ratamess, N.A., Kang, J., Rashti, S.L. and Faigenbaum, A.D. (2009). Effect of betaine supplementation on power performance and fatigue. Journal of the International Society of Sports Nutrition, 6, 7. https://doi.org/10.1186/1550-2783-67

Jastrebova, J., Witthoft, C., Grahn, A., Svensson, U. and Jagerstad, M. (2003). HPLC Determination of folates in raw and processed beetroots. Food Chemistry, 80 (4), 579-588. https://doi.org/10.1016/S0308-8146 (02)00506-X

Kavalcova, P., Bystricka, J., Tomas, J., Karovicova, J., Kovarovic, J. and Lenkova, M. (2015). The content of total polyphenol and antioxidant activity in red beetroot. India Food Science Journal, 9, 77-83. https://doi.org/10.5219/441

Kohajdova, Z., Karovicova. J., Magala, M. and Laukova, M. (2018). Utilisation of beetroot powder for bakery applications. Chemistry Paper, 72, 1507-1515. https://doi.org/10.1007/s11696-018-0392-z

Larrauri, J.A. (1999). New approaches in the preparation of high dietary fibre powders from fruit by-products. 
Trends in Food Science and Technology, 10(1), 3-8. https://doi.org/10.1016/S0924-2244(99)00016-3

Mudambi, R. (1989). Food Science. Delhi: New Delhi Eastern Ltd.

Nazni, P. and Karuna Thara, D. (2011). Optimization of beetroot peel osmotic dehydration process using response surface methodology. International Journal of Current Research, 3(8), 027-032.

Neagu, C. and Barbu, V. (2014). Principal component analysis of the factors involved in the extraction of beetroot betalains. Journal of Agroalimentary Processes and Technologies, 20(4), 311-318.

Panse, Y.E. and Sukhatme, P.V. (1961). Statistical methods of agricultural workers. $2^{\text {nd }}$ ed., p. 12-87. New Delhi, India: Indian council of Agricultural Research.

Patil, H. and Pol, R. (2014). A Study on Effects of Standardized Recipes of Bakery Products in Pune Region. International Journal of Multidisciplinary Consortium, 1(3), 82-91.

Pinki, P.A. (2014). Sensory and nutritional evaluation of value added cakes formulated by incorporating beetroot powder. International Journal of Food Science and Nutrition, 3(60, 145-148.

harma, S., Peter, S., Parimita., Phughe, T. and Ahmad, S. (2019). Studies on cup-cakes incorporated with beetroot and wheatgrass powder. International Journal of Food Science and Nutrition, 4(4), 206208.

Singh, J.P., Kaur, A., Shevkani, K., Singh, N. and Singh, B. (2016). Physicochemical characterization of corn extrudates prepared with varying levels of beetroot (Beta vulgaris) at different extrusion temperatures. International Journal of Food Science and Technology, 51(4), 911-919. https://doi.org/10.1111/ ijfs.13051

Srivastava, S. and Singh, K. (2018). Nutritional Differences found in two values added baked products of beetroot (Beta vulgaris). International Journal of Science, Engineering and Management, 3 (4), 209-212.

Srivastava, S. and Singh, K. (2016). Physical, Sensory and Nutritional Evaluation of Biscuits Prepared By Using Beetroot (Beta vulgaris) Powder. International Journal of Innovative Research and Advanced Studies, 3(7), 281-283.

Vali, L., Stefanovits-Banyai, E., Szentmihalyi, K., Febel Sardi, H., Lugasi, E., Kocsis, A. and Blazovics, I. (2007). Liver-protecting effects of table beet (Beta vulgaris var. Rubra) during ischemia-reperfusion. Nutrition, 23(2), 172-178. https://doi.org/10.1016/ j.nut.2006.11.004 